\title{
PEMENUHAN HAK ANAK DI INDONESIA MELALUI PERENCANAAN PENGASUHAN, PENGASUHAN TUNGGAL DAN PENGASUHAN BERSAMA
}

\author{
Rika Saraswati \\ Fakultas Hukum dan Komunikasi, Universitas Katolik Soegijapranata \\ email: rikasaraswati@unika.ac.id \\ Emanuel Boputra \\ Fakultas Hukum dan Komunikasi, Universitas Katolik Soegijapranata \\ email: emanuel@unika.ac.id \\ Yuni Kusniati \\ Fakultas Hukum dan Komunikasi, Universitas Katolik Soegijapranata \\ email: yunika@unika.ac.id
}

disampaikan 6/3/2020 - di-review 27/7/2020 - diterima 31/5/2021

DOI: $10.25123 /$ vej.v7i1.4066

\begin{abstract}
In many countries, joint custody has replaced and is considered better than sole custody. It is also deemed more in line with the gender equality principle which demands both parents to share responsibility for the custody and care of the child post-divorce. This article discusses how judges in divorce cases decide on child custody, and the extent to which they consider the merits of joint or sole custody and demand divorcees to consider making a parenting plan in the best interest of their children. Qualitative data is collected from the District Court and Religious Court at Semarang and by analysing 4 court decisions regarding child custody. Interestingly, none of the Courts above possess or implements a policy or have some procedural ruling obligating judges in divorce cases to demand parents to consider joint custody or making a parenting plan post-divorce. Obligatory pre-trial mediation is geared more as a procedural-formalistic attempt to dissuade parties to continue with divorce.
\end{abstract}

Keywords:

Sole-Joint custody, gender equality, parenting plans, divorce

\begin{abstract}
Abstrak
Konsep pengasuhan bersama, di dalam beberapa sistem hukum berbeda, sudah menggantikan pengasuhan tunggal. Alasannya adalah pengasuhan tunggal dianggap tidak lagi sesuai dengan nilai-nilai kesetaraan gender dan sebaiknya urusan mengasuh anak melibatkan kedua orang tua. Fokus tulisan ini adalah pada bagaimana hakim menanggapi dan memutus persoalan pengasuhan anak dalam konteks Pasal 41 UU Nomor 1 Tahun 1974 tentang Perkawinan (diubah melalui UU Nomor 16 Tahun 2019), serta mengawasi pembuatan dan pelaksanaan rencana pengasuhan dari kedua orang tua pasca perceraian. Penelaahan dilakukan dengan menganalisis data kualitatifkuantatif yang diambil dari Pengadilan Negeri dan Agama di Semarang serta dengan mengkaji 4 putusan tentang hak asuh. Temuan menarik adalah Pengadilan tampaknya tidak memilki kebijakan atau panduan bagi hakim berkenaan dengan menetapkan kewajiban pasangan membuat rencana pengasuhan pasca putusan cerai. Sementara itu mediasi pra-sidang dilakukan dengan tujuan utama mendamaikan pihak yang mengajukan permohonan cerai.
\end{abstract}

Kata kunci: pengasuhan tunggal-bersama, kesetaraan gender, perencanaan pengasuhan, perceraian 


\section{Pendahuluan}

Penelitian ini dilatarbelakangi situasi adanya perubahan di dalam sistem hukum di beberapa negara dalam mengatur pengasuhan anak setelah perkawinan orang tuanya berakhir karena perceraian di mana pengasuhan tunggal dianggap tidak sesuai lagi dengan nilai-nilai kesetaraan gender, sehingga pengasuhan yang baik setelah terjadinya perceraian sebaiknya tetap melibatkan kedua orang tua melalui pengasuhan bersama.

Ketentuan terkait dengan pengasuhan anak setelah perkawinan orang tua berakhir karena putusan pengadilan diatur di dalam Pasal 41 UU Nomor 1 Tahun 1974 tentang Perkawinan (yang telah mengalami perubahan melalui UU Nomor 16 Tahun 2019, selanjutnya disebut UU Perkawinan). Pasal tersebut menentukan bahwa baik ibu atau bapak tetap berkewajiban memelihara dan mendidik anakanaknya, semata-mata berdasarkan kepentingan anak; bilamana ada perselisihan mengenai penguasaan anak-anak maka Pengadilan yang akan memberi keputusannya. Pasal 41 UU Perkawinan juga mengatur jika bapak dalam kenyataan tidak dapat memenuhi kewajiban tersebut maka Pengadilan dapat menentukan bahwa ibu ikut memikul biaya tersebut. Pasal 49 UU Perkawinan selanjutnya mengatur bahwa ayah atau ibu yang berkelakuan buruk sekali atau sangat melalaikan kewajibannya dapat dicabut kekuasaannya sebagai orangtua tanpa mencabut kewajiban-kewajibannya kepada anaknya untuk memberi biaya pemeliharaan.

Ketentuan lain yang terkait dengan pengasuhan ada di dalam Pasal 105 Kompilasi Hukum Islam (selanjutnya disebut dengan KHI) yang menentukan bahwa pemeliharaan anak yang belum mumayyiz atau belum berumur 12 tahun adalah hak ibunya; dalam hal anak sudah mumayyiz maka ia berhak memilih untuk mendapatkan hak asuh dari ayah atau ibunya. Semua biaya pengasuhan dan nafkah anak menjadi tanggungan ayah menurut kemampuannya, sekurangkurangnya sampai anak tersebut dewasa dan dapat mengurus diri sendiri (21 tahun). Kewajiban ayah ini termasuk kepada anak yang tidak turut dengannya (Pasal $156 \mathrm{KHI}$ ). 
Berdasarkan hasil penelitian di beberapa negara diperoleh beberapa kriteria yang dapat digunakan untuk menetapkan hak asuh asuh, yaitu: (1) keinginan orang tua, (2) keinginan anak, (3) hubungan antar anak, orang tua, saudara kandung dan orang lain yang memberikan pengaruh signifikan pada kepentingan terbaik anak, (4) penyesuaian anak di rumah, sekolah dan masyarakat, (5) kesehatan fisik dan mental orang-orang yang terlibat dengan anak. ${ }^{1}$ Kelima hal ini sangat bersifat psikologis karena berhubungan dengan pengukuran kualitas hubungan antarpribadi, kelekatan emosional antara orang tua dan anak, kemampuan mengatasi masalah dan konsistensi serta stabilitas hubungan dari waktu ke waktu. Dengan demikian dalam menentukan siapa yang dianggap sebagai pengasuh utama, pengadilan akan melihat orang tua yang mana yang membelikan dan mencucikan pakaian anaknya, siapa yang memandikan dan mendandani anaknya, siapa yang menanamkan disiplin kepada anak, siapa yang menyiapkan makanan dan menyuapi anaknya, siapa yang membantu mengerjakan pekerjaan rumah anaknya, siapa yang menidurkan anaknya di malam hari dan membangunkannya di pagi hari, siapa yang merawat anaknya ketika sakit dan membawanya ke dokter, dan siapa yang mengatur waktu bermain anak dengan teman-temannya. Hal ini yang disebut dengan primary caretaker preference (preferensi pengasuh primer), di mana pengadilan harus memberikan hak asuh primer kepada orang tua yang menjadi penanggung jawab utama dalam proses membesarkan anak mereka sebelum terjadi perceraian. ${ }^{2}$

Hak untuk memelihara anak oleh seorang ibu atau ayah telah mengalami perubahan. Pada awal abad ke sembilan belas, hak untuk memelihara atau mengasuh anak (the right of custody) semula diyakini tepat untuk diberikan kepada ayah; kemudian bergeser ke pandangan bahwa ibu adalah pihak yang tepat untuk mendapatkannya. Alasan pergeseran pandangan tersebut didasarkan pada suatu teori bahwa seorang ibu harus memelihara dan merawat anak-anak

1 Linda. D Elrod. and M. D. Dale, 'Paradigm Shifts and Pendulum Swings in Child Custody: The Interests of Children in the Balance' 42(3) Family Law Q. 381, 2008.

2 R.F. Cochran Jr. 'The Search for Guidance in Determining the Best Interests of the Child at Divorce: Reconciling the Primary Caretaker and Joint Custody Preferences' 20(1) University of Richmond Law Rev. 1985. 
yang usianya masih rawan (tender years). Hal ini tentunya dengan pengecualian, apabila si ibu ternyata tidak pantas mendapatkan hak tersebut atas dasar kepentingan terbaik bagi anak. Pada tahun 1970an, para ahli di bidang kesehatan mental menyarankan agar pengasuhan tunggal (sole custody) harus diserahkan kepada orang tua yang secara psikologis memiliki keterikatan atau kebersamaan bersama anak sebagai hal yang utama. ${ }^{3}$ Akan tetapi, seiring dengan semakin banyak perempuan yang bekerja dan banyak para ayah yang mencari dan memperjuangkan hak pengasuhan atas anak-anaknya maka nilai-nilai kesetaraan gender berpengaruh pada hubungan pengasuhan sehingga konsep pengasuhan tunggal (sole custody) yang biasanya diberikan kepada ibu menjadi hal yang tidak mutlak dan kemudian memunculkan konsep pengasuhan bersama (joint custody). ${ }^{4}$

Konsep pengasuhan bersama kemudian dianggap sebagai bentuk pengasuhan yang tepat di negara-negara barat, seperti Australia, ${ }^{5}$ Amerika, ${ }^{6}$ Kanada $^{7}$ dan negara lainnya. Konsep ini mewajibkan kedua orang tua untuk membuat kesepakatan yang terkait dengan kebutuhan dan kepentingan anak di semua aspek kehidupan. ${ }^{8}$ Pengasuhan bersama ini bukannya tanpa kekurangan, terutama jika pengadilan tidak jeli dalam mendalami penyebab terjadinya perceraian, misalnya: ketidakstabilan jiwa/emosi seseorang, penolakan anak untuk bertemu orang tua, kekerasan dalam rumah tangga, dan dugaan penyalahgunaan kekuasaan. ${ }^{9}$

Pengadilan membedakan antara legal custody dan physical custody. Legal custody (hak asuh legal) merupakan bentuk pengasuhan yang berhubungan dengan hak dan tanggungjawab orang tua, misalnya menentukan anaknya harus

\footnotetext{
Id.

4 Linda D Eldrod, Reforming the System to Protect Children in High Conflict Custody Cases, 28(2) William Mitchell Law Review. 506, 2001.

5 Lawrie Moloney, Child Focused Parenting after Separation: Socio legal Developments and Challenges, 21(2) ANZJ Fam. 61, 2000.

6 J.Herbie DiFonzo, From the Rule of One to Shared Parenting: Custody Presumptions in Law and Policy, 52 (2) Family Court Review. 214, 2014.

7 Martha Saffer, 2007, Joint Custody, Parental Conflict and Children's Adjustment to Divorce: What the Social Science Literature Does and Does Not Tell Us, 26(3) Canadian Family Law Quarterly. 285, 2007; Lihat juga Barbara J Fidler and Rachel Birnbaum, Child Custody Disputes: Private and Public Assesment, 25(2) Canadian Family Law Quarterly. 137, 140. 2006

8 Cochran, supra no. 2.
}

9 Id. 
sekolah di mana, penanganan medis yang harus diterima; keputusan demikian harus dinegosiasikan bila kedua orang tua anak berbagi hak asuh legal. Physical custody (hak asuh fisik) merupakan bentuk pengasuhan yang mengacu pada berapa lama seorang anak dapat menghabiskan waktu bersama salah satu orang tua. Jika kedua orang tua anak berbagi hak asuh fisik, anak tinggal dengan masingmasing orang tua dengan jangka waktu tertentu.

Hak asuh tunggal (sole custody) adalah bentuk pengasuhan di mana salah satu orang tua memiliki hak asuh legal dan fisik, sementara yang lainnya secara umum hanya diberi hak-hak terbatas untuk mengunjungi anaknya dengan masa kunjungan yang teratur. Hak asuh tunggal lebih disukai bila salah satu orang tua jelas-jelas tidak kompeten, atau bila kondisi anak yang rentan yang harus dilindungi dari konflik-konflik yang sering muncul karena orang tua saling bermusuhan (sementara mereka harus berbagi hak asuh dan masih sering berinteraksi dalam mengatur jadwal kunjungan dan dalam mengambil berbagai keputusan tentang anak). ${ }^{10}$

Hak asuh bersama juga semakin sering diterapkan-keuntungan utamanya adalah bahwa pengasuhan ini memastikan bahwa kedua orangtua anak terlibat dalam proses membesarkan anaknya. Selain itu, dukungan finansial untuk anak lebih stabil dibandingkan hak asuh tunggal karena orang tua yang diberi hak asuh harus selalu meminta pembayaran biaya pengasuhan dari orang tua yang tidak memiliki hak asuh. Hanya saja, ada ketidakuntungannya terutama bagi kedua orang tua yang mungkin saling membenci karena mereka harus berkomunikasi, bekerjasama dan berkoordinasi.

Perkembangan berikutnya menunjukkan bahwa di sebagian besar negara mulai mensyaratkan asas the best interest of the child (kepentingan terbaik anak) sebagai dasar menentukan hak atas pengasuhan. ${ }^{11}$ Kepentingan terbaik anak'

\footnotetext{
Id.

11 J. H. DiFonzo, 'From the Rule of One to Shared Parenting: Custody Presumptions in Law and Policy'. 52(2) Family Court Rev. 214, 2014; L. Moloney, 'Child Focused Parenting after Separation: Socio Legal Developments and Challenges' 21(2) Australian and New Zealand J. of the Family 61, 2000.. For the UK experience, see UK Parliament Justice Committee, Operation of the Family Courts: 4. Underpinning Principles

$<$ https://publications.parliament.uk/pa/cm201012/cmselect/cmjust/518/51807.htm>accessed
} 
ditentukan dengan memastikan terpenuhi dan terjaminnya kebutuhan anak-anak untuk dicintai, untuk mendapatkan kasih sayang, bimbingan dan pendidikan berkelanjutan. Hal ini menunjukkan bahwa kepentingan anak menjadi pertimbangan yang utama daripada kebutuhan orang tua dan pihak-pihak lain yang berkepentingan. ${ }^{12}$ Melalui asas ini, maka tidak ada praduga bahwa si ayah atau si ibu yang lebih berhak mendapatkan hak asuh anak. Tujuan lebih tinggi yang hendak dicapai melalui asas ini adalah untuk menempatkan anak di lingkungan yang paling menguntungkan dan yang memungkinkan untuk berkembang dengan sehat.

Asas kepentingan yang terbaik bagi anak menurut penjelasan Pasal 2 Undang-Undang Nomor 23 Tahun 2002 tentang Perlindungan Anak (selanjutnya disebut dengan UU Perlindungan Anak Tahun 2002) yang telah diperbaharui melalui Undang-Undang Nomor 35 Tahun 2014 (selanjutnya disebut dengan UU Perlindungan Anak Tahun 2014) menyatakan bahwa dalam semua tindakan yang menyangkut anak yang dilakukan oleh pemerintah, masyarakat, badan legislatif, dan badan yudikatif, maka kepentingan yang terbaik bagi anak harus menjadi pertimbangan utama karena anak merupakan kelompok/pihak yang rentan yang harus mendapat perlindungan dari pemerintah. ${ }^{13}$ Oleh karena itu, asas ini menjadi sangat penting sebagai pedoman bagi hakim dalam memutus kasus perceraian yang di dalamnya terdapat perselisihan mengenai hak asuh anak karena anak merupakan pihak yang rentan jika terjadi perceraian.

Pasal 41 UU Perkawinan tidak memberikan kejelasan maupun penjelasan lebih lanjut mengenai 'kepentingan' anak; Pasal 41 UU Perkawinan hanya menyebutkan bahwa: “Akibat putusnya perkawinan karena perceraian ialah: baik

30 March 2019, pukul. 18:00; M. Saffer, 'Joint Custody, Parental Conflict and Children's

Adjustment to Divorce: What the Social Science Literature Does and Does Not Tell Us' 26(3) Cdn. Family Law Q. 285, 2007; B. J. Fidler and R. Birnbaum, 'Child Custody Disputes: Private and Public Assessment' 25(2) Cdn. Family Law Q. 137, 2006; N. Bala, V. Talwar and J. Harris, 'The Voice of Children in Canadian Family Law Cases' 24 Cdn. Family Law Q. 221, 2005.

12 Rika Saraswati, Emanuel Boputra dan Yuni Kusniati, Tinjauan terhadap Sistem Pengasuhan Anak dari Pengasuhan Tunggal Menjadi Pengasuhan Bersama sebagai Perwujudan Pemenuhan Asas Kepentingan Terbaik Anak, penelitian-LPPM Universitas Katolik Soegijapranata, tidak dipublikasikan, 27-30, 2018.

13 Rika Saraswati, Hukum Perlindungan Anak di Indonesia, Citra Aditya Bakti, Bandung, 2015, hlm., 25-26. 
ibu atau bapak tetap berkewajiban memelihara dan mendidik anak-anaknya, semata-mata berdasarkan kepentingan anak, bilamana ada perselisihan mengenai penguasaan anak-anak". Faktor-faktor tersebut tentunya akan berpengaruh terhadap keputusan Hakim dalam menentukan hak asuh anak.

Untuk mengetahui sejauhmana konsep pengasuhan bersama sebagai perwujudan asas kepentingan terbaik bagi anak telah diadopsi oleh Hakim di Indonesia melalui putusan pengadilan, maka penulis melakukan penelitian di Pengadilan Agama Semarang dan Pengadilan Negeri Semarang melalui beberapa putusan pengadilan mengenai perkara perceraian yang disertai dengan permohonan hak asuh anak. Pertimbangan dipilihnya Pengadilan Negeri Semarang dan Pengadilan Agama Semarang karena kedua Pengadilan ini memiliki tugas dan kewenangan, serta yurisdiksi dalam menangani kasus-kasus yang terkait dengan perceraian dan hak asuh anak sebagaimana yang diatur di dalam peraturan perundang-undangan nasional, dan kasus-kasus tersebut juga memiliki keterkaitan dengan asas kepentingan terbaik anak dan hak-hak anak sebagai akibat perceraian yang diatur di dalam UU Perlindungan Anak. Putusan Pengadilan yang diteliti adalah putusan tentang perceraian yang disertai dengan permohonan hak asuh anak sejumlah empat (4) di tahun 2014 hingga 2017. Pertimbangan diambilnya putusan pengadilan pada kurun waktu tersebut adalah untuk mengetahui pengetahuan hakim setelah diundangkannya UU Nomor 35 Tahun 2014 tentang Perubahan Atas UU Nomor 23 Tahun 2002 tentang Perlindungan Anak khususnya tentang asas kepentingan terbaik bagi anak (yang diatur di dalam Pasal 2 UU Perlindungan Anak Tahun 2002) dan hak anak untuk bertemu orangtuanya setelah perpisahan - hak yang merupakan 'roh' dan salah satu bagian dari konsep pengasuhan bersama (yang diatur di dalam Pasal 14 UU Perlindungan Anak Tahun 2014).

Pengumpulan data dilakukan dengan cara memberikan kuesioner yang dibuat dengan sistem terbuka kepada empat (4) Hakim di Pengadilan Negeri Semarang dan satu (1) Hakim di Pengadilan Agama Semarang yang semuanya pernah memutus kasus perceraian yang disertai dengan permohonan hak asuh 
anak. Wawancara juga dilakukan kepada kelima hakim yang diberi kuesioner tersebut sebagai klarifikasi terhadap jawaban-jawaban atas kuesioner yang dirasakan kurang jelas. Data yang terkumpul kemudian dianalisis secara deskriptif kualitatif sehingga dapat diperoleh gambaran yang menyeluruh mengenai dasar pertimbangan hakim (termasuk penerapan asas kepentingan terbaik anak) dalam memutus kasus perceraian dengan permohonan hak asuh anak dan kepada siapa hak asuh anak diberikan oleh hakim. Dengan demikian maka dapat diketahui sejauh mana hakim telah mengenal dan memperkenalkan konsep pengasuhan bersama terhadap pasangan suami-istri yang hendak bercerai, dan sejauh mana konsep tersebut diterapkan di dalam putusannya.

\section{Pembahasan}

\section{Pendapat Hakim Mengenai Konsep Pengasuhan di dalam UU Perkawinan}

Hak untuk memelihara atau hak asuh terhadap anak sebagai akibat perceraian sebagaimana tersebut dalam Pasal 41 UU Perkawinan tidak menyebut dengan jelas sebagai hak asuh tunggal ataukah hak asuh bersama. Akan tetapi para hakim di Pengadilan Negeri Semarang (4 orang) dan Pengadilan Agama Semarang (1 orang) yang telah menjawab kuesioner dan diwawancarai menyatakan bahwa pengasuhan anak menurut UU Perkawinan adalah hak asuh bersama karena suami dan istri yang telah bercerai tetap mempunyai kewajiban sebagai orangtua, yaitu mendidik dan memelihara anak secara bersama-sama. Mereka berpendapat bahwa meskipun kebanyakan hak asuh atau hak memelihara diberikan kepada salah satu orang tua, tetapi dapat juga diberikan kepada kedua orang tua sebagai 'hak asuh bersama' karena tidak dilarang. ${ }^{14}$ Menurut para hakim, bentuk pengasuhan yang diatur oleh UU Perkawinan merupakan pengasuhan bersama karena ibu dan bapak tetap berkewajiban memelihara dan mendidik anaknya semata-mata berdasarkan kepentingan anak, kecuali ada perselisihan maka pengadilan memberikan putusan (Pasal 41 dan 45 UU Perkawinan).15

14 Rika Saraswati, Emanuel Boputra dan Yuni Kusniati, supra no. 12. 15 Id. 
Meskipun para hakim menyatakan bahwa pengasuhan dalam UU Perkawinan merupakan pengasuhan bersama, hal-hal yang terkait dengan kesepakatan mengenai dalam hal apa dan bagaimana cara pengasuhan bersama itu akan dilakukan tidak jelas. Ketidakjelasan terjadi karena tidak ada ketentuan yang mengaturnya sebagaimana yang dinyatakan oleh para hakim yang diwawancarai (lihat tabel berikut).

Tabel 1: Ketentuan Hak Asuh Bersama di Indonesia

\begin{tabular}{ll}
\hline \multicolumn{1}{c}{ Hakim } & \multicolumn{1}{c}{ Jawaban } \\
\hline Hakim PN16 & Tidak jelas diatur \\
\hline Hakim PN17 & $\begin{array}{l}\text { Ada, yaitu pasal 41 dan Pasal 45 UU Perkawinan, dan UU Nomor 23 Tahun 2002 } \\
\text { tentang Perlindungan Anak }\end{array}$ \\
\hline Hakim PN 18 & Ketentuan khusus tidak ada \\
\hline Hakim PN19 & $\begin{array}{l}\text { Belum ada ketentuan khusus, hanya mengacu pada UU Perlindungan Anak, } \\
\text { namun bisa diarahkan untuk membuat kesepakatan bersama antara orangtua } \\
\text { demi kebaikan dan tumbuh kembang anaknya. }\end{array}$ \\
\hline Hakim PA ${ }^{20}$ & $\begin{array}{l}\text { Tidak ada, kalau perkara hak asuh anak menjadi ranah sengketa di pengadilan } \\
\text { maka harus ditetapkan pada salah satu pihak }\end{array}$ \\
\hline Sumber: Rika Saraswati, Emanuel Boputra dan Yuni Kusniti, 201821
\end{tabular}

Sumber: Rika Saraswati, Emanuel Boputra dan Yuni Kusniati, $2018^{21}$

Para hakim tersebut menganggap bahwa kesepakatan untuk mengasuh bersama tetap perlu dilakukan meskipun hak asuh tunggal (sole custody) telah ditetapkan oleh pengadilan. Beberapa hakim menganggap tidak perlu mengubah konsep hak asuh tunggal menjadi hak asuh bersama dengan alasan kedua bentuk pengasuhan tersebut tetap dapat digunakan bersama-sama atau sendiri-sendiri tergantung pada kebutuhan dan kepentingan anak. Selain itu, hakim berpendapat bahwa selama hak asuh menjadi obyek sengketa maka konsep hak asuh bersama tidak bisa diterapkan. Akan tetapi, terdapat hakim yang memandang bahwa hak asuh bersama melalui kesepakatan bersama adalah hal yang penting dan dapat diusulkan untuk diatur secara khusus dalam peraturan perundang-undangan. ${ }^{22}$ Mengingat tidak ada kejelasan peraturan mengenai hal tersebut maka dalam

\footnotetext{
16 Kuesioner dan wawancara dengan Hakim EP pada tanggal 19 Juli 2018, pukul 10:00.

17 Kuesioner dan wawancara dengan Hakim MY pada tanggal 19 Juli 2018, pukul 10:00.

18 Kuesioner dan wawancara dengan Hakim NN pada tanggal 19 Juli 2018, pukul 10:45.

19 Kuesioner dan wawancara dengan Hakim EN pada tanggal 19 Juli 2018, pukul 10:45.

20 Kuesioner dan wawancara dengan Hakim MS pada tanggal 16 Juli 2018, pukul 09:00.

21 Rika Saraswati, Emanuel Boputra dan Yuni Kusniati, supra no. 12.

22 Id.
} 
pelaksanaannya ada beberapa hakim yang pernah dan tidak pernah memerintahkan para pihak untuk membuat kesepakatan dalam melakukan pengasuhan bersama (lihat tabel berikut ini).

Tabel 2: Hakim Memerintahkan Membuat Kesepakatan tentang Hak Asuh Bersama dan Menuangkan ke Dalam Perjanjian

\begin{tabular}{|c|c|c|}
\hline Hakim & Di luar Pengadilan & Di dalam Pengadilan \\
\hline Hakim $\mathrm{PN}^{23}$ & Tidak pernah & Belum pernah \\
\hline Hakim $\mathrm{PN}^{24}$ & $\begin{array}{l}\text { Tidak pernah karena } r \\
\text { pengasuhan anak adalah perintah } \\
\text { undang-undang, kecuali } \\
\text { kenyataannya diperoleh fakta bahwa } \\
\text { hak pengasuhan itu dibebankan kepada } \\
\text { salah satu pihak maka dituangkan dalam } \\
\text { pertimbangan dan putusan hakim }\end{array}$ & $\begin{array}{l}\text { Tidak pernah karena cukup } \\
\text { dengan keputusan pengadilan. }\end{array}$ \\
\hline Hakim $\mathrm{PN}^{25}$ & $\begin{array}{l}\text { Pernah memerintahkan tetapi tidak } \\
\text { dilaksanakan }\end{array}$ & $\begin{array}{l}\text { Kalau memerintah atau memutus- } \\
\text { kan belum pernah karena tidak } \\
\text { dituangkan dalam perjanjian, } \\
\text { tetapi kesepakatan lisan }\end{array}$ \\
\hline Hakim PN26 & $\begin{array}{l}\text { Seharusnya dilakukan namun jarang } \\
\text { terjadi }\end{array}$ & $\begin{array}{l}\text { Pernah, terutama saat mediasi oleh } \\
\text { mediator hakim }\end{array}$ \\
\hline Hakim $\mathrm{PA}^{27}$ & $\begin{array}{l}\text { Pernah, memutus perkara yang telah } \\
\text { disepakati oleh kedua belah pihak ketika } \\
\text { kesepakatan itu tercapai pada saat } \\
\text { mediasi }\end{array}$ & $\begin{array}{l}\text { Tidak pernah karena biasanya } \\
\text { hakim hanya menganjurkan agar } \\
\text { kedua belah pihak membuat } \\
\text { kesepakatan }\end{array}$ \\
\hline
\end{tabular}

Sumber: Rika Saraswati, Emanuel Boputra dan Yuni Kusniati, $2018^{28}$

Ketiadaan ketentuan telah menyebabkan para hakim jarang sekali menyarankan para pihak untuk menjalankan kewajibannya sebagaimana yang diatur di dalam UU Perkawinan, dalam hal ini ayah dan ibu terlepas yang bersangkutan ditetapkan sebagai pemegang hak asuh atau tidak. Mengingat jarang sekali para pihak yang bercerai membuat kesepakatan bersama untuk tetap memelihara dan memenuhi kebutuhan anak lahir dan batin secara bersama setelah perceraian, maka ada beberapa hakim yang memerintahkan kepada para pihak untuk tidak membatasi akses bertemu anak dari pihak lain yang tidak mendapatkan hak asuhnya; tidak membatasi akses untuk bertemu anak terhadap pihak lain yang tidak mendapatkan hak asuh dianggap sebagai bentuk

23 Kuesioner dan wawancara dengan Hakim EP pada tanggal 19 Juli 2018, pukul 10:00.

24 Kuesioner dan wawancara dengan Hakim MY pada tanggal 19 Juli 2018, pukul 10:00.

25 Kuesioner dan wawancara dengan Hakim NN pada tanggal 19 Juli 2018, pukul 10:45.

26 Kuesioner dan wawancara dengan Hakim EN pada tanggal 19 Juli 2018, pukul 10:45.

27 Kuesioner dan wawancara dengan Hakim MS pada tanggal 16 Juli 2018, pukul 09:00.

28 Rika Saraswati, Emanuel Boputra dan Yuni Kusniati, supra no.12. 
perwujudan hak asuh bersama oleh hakim. ${ }^{29}$ Akan tetapi, tidak semua hakim melakukannya karena hakim tersebut berpendapat bahwa akibat perceraian terhadap pengasuhan anak tetap terbatas diatur dalam UU Perkawinan, kecuali ada permohonan dan didukung dengan fakta serta alasan yang cukup barulah ditetapkan. ${ }^{30}$

Meskipun para hakim berbeda pendapat mengenai penerapan hak asuh bersama di dalam proses peradilan, pada prinsipnya mereka setuju dengan konsep hak asuh bersama ini karena baik untuk masa depan dan kejiwaan anak. Selain itu, para hakim berpendapat bahwa hak asuh bersama adalah yang utama karena tidak ada yang bisa menggantikan kasih sayang orang tua pada anaknya. Selain itu, perlu juga ditentukan dengan siapa saja anak akan tinggal dengan orang tua yang dianggap nyaman dan baik untuk tumbuh kembang anak sehingga tidak ada tekanan psikis pada anak setelah perceraian terjadi. Terdapat hakim yang berpendapat bahwa hakim tidak menyatakan hak asuh bersama tetapi sebaliknya hak asuh kepada anak menjadi status quo dalam arti hakim tidak akan mengubah situasi dan kondisi yang ada yang dihadapi anak sehari-hari dalam hubungannya dengan orangtuanya yang saling berselisih atau berpisah karena menurut hakim situasi dan kondisi tersebut sudah baik untuk kehidupan dan perkembangan anak di saat ini dan di masa depan. ${ }^{31}$

\section{Pengasuhan Tunggal dan Pengasuhan Bersama dalam Putusan Pengadilan}

Melalui empat (4) putusan yang diteliti terkait dengan kasus perceraian dan permohonan hak asuh anak sepanjang tahun 2014-2017, maka dapat diketahui bahwa majelis hakim telah berusaha untuk memenuhi prinsip kepentingan terbaik anak (sebagaimana yang diamanatkan oleh UU Perlindungan Anak tahun 2002 dan 2014). Prinsip kepentingan terbaik bagi anak telah diletakkan oleh majelis hakim sebagai prinsip yang utama daripada kebutuhan orang tua dan pihak-pihak lain yang berkepentingan. Selain itu, berdasarkan asas ini maka tidak ada praduga bahwa si ayah atau si ibu yang lebih berhak

\footnotetext{
29 Id.

30 Id.

31 Id.
} 
mendapatkan hak asuh anak. Tujuan lebih tinggi adalah menempatkan anak di lingkungan yang paling menguntungkannya dan lingkungan yang memungkinkannya untuk berkembang dengan sehat.

Salah satu contoh pertimbangan majelis hakim dalam Putusan Pengadilan Nomor: 1901/Pdt.G/2017/PA.Smg yang diteliti memilih untuk tidak memberikan hak asuh kepada salah satu pihak tetapi mendasarkan pada status quo yang ada demi kepentingan terbaik anak. Majelis hakim dalam putusan tersebut tidak menyebutkan kata konflik, namun pertimbangan yang diberikan telah menyiratkan bahwa hak asuh bersama yang diputuskan oleh hakim bertujuan mengurangi konflik yang mungkin timbul.

"Berdasarkan fakta-fakta yang ada dan kepentingan anak maka Majelis Hakim berpendapat kedua orang anak Penggugat dan Tergugat tersebut tidak akan ditetapkan kepada Penggugat maupun Tergugat dan dengan tetap berada pada status seperti sekarang dengan diasuh oleh Penggugat dan Tergugat sebagai ibu dan ayahnya, seperti yang telah berjalan pada waktu kedua orangtuanya berpisah rumah, dengan tetap memberikan kebebasan kepada Penggugat dan Tergugat selaku orangtua untuk mencurahkan kasih sayangnya masing-masing (Pasal 5 ayat 1 dan 2 UU Nomor 1 Tahun 1974 tentang Perkawinan)".32

Dengan menggunakan asas kepentingan terbaik bagi anak maka standar ini mengharuskan pengadilan untuk memprediksi masa depan si anak. Oleh karena itu, hakim harus membayangkan mengenai bentuk pengasuhan seperti apa yang memungkinkan perkembangan yang sehat selama masa kanak-kanak atau selama beberapa puluh tahun setelah keputusan itu diambil. Hal ini terlihat dalam Putusan Pengadilan Nomor: 217/Pdt.G/2014/PN.SMG di mana di dalam pertimbangannya majelis hakim menyatakan bahwa:

"...Mengingat kedua anak masih berada di bawah umur dan secara psikologis hubungan lebih dekat dengan ibunya (Penggugat) karena seharihari diasuh oleh penggugat, maka sudah sepatutnya anak tersebut di bawah asuhan dan bimbingan Penggugat. Anak-anak penggugat mengikuti dan tinggal dengan Penggugat selaku ibunya hingga dewasa dan berdiri sendiri, dengan ketentuan apabila Tergugat selaku ayah kandung anak tersebut ingin mengunjungi atau bertemu anaknya untuk saling

32 Putusan Pengadilan Nomor: 1901/Pdt.G/2017/PA.Smg, hlm., 33. 
memberikan kasih sayang, Penggugat tidak menghalangi dan melarangnya". 33

Selanjutnya, pertimbangan majelis hakim pada Putusan Pengadilan Nomor: 428/Pdt.G/2014/PN.Smg menyebutkan:

"... Majelis Hakim berpendapat bahwa anak-anak tersebut akan lebih tepat apabila pengasuhan, pemeliharaan dan pendidikannya diserahkan kepada Penggugat sebagai ibunya dengan tanpa mengurangi kewajiban Tergugat sebagai bapaknya untuk memberikan biaya pemeliharaan dan pendidikan bagi anak-anaknya". ${ }^{34}$

Berdasarkan putusan-putusan tersebut terlihat bahwa ada majelis hakim yang menggunakan hak asuh tunggal (sole custody) dan memberi kesempatan pihak yang lain yang tidak diberi hak asuh untuk tetap menjalankan kewajibannya sebagai orang tua dan memberi akses pihak yang tidak diberi hak asuh untuk tetap bertemu dengan anak-anak dengan tujuan agar para pihak bisa saling memberikan kasih saying; akses ini hanya bisa dilakukan apabila pihak yang diberi hak asuh tunggal tidak menghalangi dan melarangnya.

Hak asuh tunggal lebih disukai oleh hakim apabila salah satu orang tua jelas-jelas tidak kompeten. Akan tetapi, dalam kasus-kasus di mana kedua orang tua kompeten dan peduli pada anak ternyata hak asuh tunggal tetap dianggap lebih baik, terutama bila kondisi anak yang rentan yang harus dilindungi dari konflik-konflik yang sering muncul apabila kedua orang tua saling bermusuhan dan harus berbagi hak asuh sehingga masih harus berinteraksi dalam mengatur jadwal kunjungan dan dalam mengambil berbagai keputusan tentang anak. Kelemahan dari hak asuh tunggal lebih sering terjadi ketika pihak yang tidak mendapatkan hak asuh mengabaikan kewajibannya untuk memelihara dan memberi biaya pendidikan. ${ }^{35}$

33 Putusan Pengadilan Nomor: 217/Pdt.G/2014/PN.SMG, hlm.,12.

34 Putusan Pengadilan Nomor: 428/Pdt.G/2014/PN.Smg, hlm.,10.

35 Ivan Ricardo Gitowardojo, Pemenuhan Hak Anak Untuk Bertemu Dengan Salah Satu Orang Tuanya Yang Tidak Mendapatkan Hak Asuh Setelah Terjadinya Perceraian Menurut Pasal 14 Ayat (2) Undang-Undang Nomor 35 Tahun 2014 Tentang Perubahan Atas Undang-Undang Nomor 23 Tahun 2002 Tentang Perlindungan Anak (Studi Kasus Putusan 
Kelemahan hak asuh tunggal inilah yang kemudian mendorong diterapkannya hak asuh bersama. Keuntungan utamanya adalah bahwa cara ini memastikan bahwa kedua orang tua anak terlibat dalam proses membesarkan anaknya. Selain itu, dukungan finansial untuk anak lebih stabil dibandingkan hak asuh tunggal. Berikut adalah contoh pertimbangan hakim yang menunjukkan penerapan hak asuh bersama pada Putusan Pengadilan Nomor: 1901/Pdt.G/2017/PA.Smg:

"Menimbang bahwa dari keterangan saksi-saksi Penggugat dan Tergugat ditemukan fakta bahwa Penggugat masih sering bertemu dengan kedua anaknya dan masih mencurahkan kasih sayang pada saat-saat tertentu, sedangkan Tergugat telah mengasuh kedua anak terebut dengan baik dan nyaman, Majelis Hakim berpendapat agar kenyamanan kedua orang anak terebut tidak terganggu meskipun antara Penggugat dan Tergugat bercerai maka sudah seharusnya anak tersebut dilindungi dari permasalahan kedua orangtuanya tersebut semata-mata untuk kepentingan yang terbaik bagi anak (Pasal 2 huruf (b) dan pasal 26 ayat (1) huruf (b) UU Nomor 23 Tahun 2002 yang telah diubah dengan UU Nomor 35 Tahun 2014 tentang Perlindungan Anak)". ${ }^{36}$

Berdasarkan putusan tersebut majelis hakim berpendapat kedua anak tersebut tidak akan ditetapkan kepada Penggugat maupun Tergugat dan tetap berada pada status seperti sekarang dengan diasuh oleh Penggugat dan Tergugat sebagai ibu dan ayahnya, seperti yang telah berjalan pada waktu kedua orangtuanya berpisah rumah, dengan tetap memberikan kebebasan kepada Penggugat dan Tergugat selaku orangtua untuk mencurahkan kasih sayangnya masing-masing.

Untuk membantu hakim dan mengurangi ketidakjelasan standar kepentingan terbaik anak, banyak negara-negara yang mengadopasi konsep primary caretaker preference atau preferensi dalam menentukan pengasuh utama. Primary caretaker preference mewajibkan pengadilan memberikan hak asuh yang utama kepada orangtua dalam proses membesarkan anak mereka sebelum terjadi perceraian. Penentuan siapa yang bertanggung jawab tersebut perlu dilakukan

No.30/Pdt.G/2016/PN.Smg dan Putusan No.45/Pdt.G/2016/PN.Smg), Skripsi S1, Fakultas Hukum dan Komunikasi Unika Soegijapranata Semarang, 2017. 
atas dasar pertimbangan bahwa kontinuitas pengasuhan dan kehangatan, konsistensi dan kontinuitas hubungan tersebut sangat penting dan sangat dibutuhkan bagi kesejahteraan anak. Pengadilan akan melihat siapa yang dianggap sebagai pengasuh utama dengan cara, misalnya: melihat orangtua yang mana yang membelikan dan mencucikan pakain anaknya, siapa yang memandikan dan menyiapkan segala keperluan berpakaian anaknya, siapa yang menanamkan disiplin kepada anak, siapa yang menyiapkan makanan dan menyuapi anaknya, siapa yang membantu mengerjakan pekerjaan rumah anaknya, siapa yang menidurkan anaknya di malam hari dan membangunkannya di pagi hari, siapa yang merawat anaknya ketika sakit dan membawanya ke dokter, dan siapa yang mengatur waktu bermain anak dengan teman-temannya. ${ }^{37}$

Berdasarkan putusan yang diteliti terlihat bahwa majelis hakim lebih sering memberikan hak asuh anak kepada si ibu daripada si ayah karena si anak lebih dekat dengan ibunya meskipun sang ayah yang telah berpisah rumah dengan ibunya tetap memberikan biaya pemeliharaan kepada anaknya. Dari keempat putusan yang diteliti, tiga putusan yang hak asuh anak dimohonkan oleh ibu sebagai penggugat seluruhnya diterima oleh pengadilan, sedangkan satu kasus yang dimintakan oleh ayah tidak diterima dan diputus dengan status quo. Majelis hakim menyatakan yang dimaksud dengan status quo adalah situasi atau kondisi yang ada dan dijalani oleh anak sebelum perceraian tetap berlangsung sebagaimana adanya. Hal ini telah menunjukkan bahwa majelis hakim (melalui Putusan Pengadilan Nomor: 1901/Pdt.G/2017/PA.Smg) tetap menggunakan konsep hak asuh tunggal dan hak asuh bersama secara bersama-sama.

Selanjutnya, berdasarkan hasil penelitian dapat diketahui pula bahwa kriteria yang digunakan oleh majelis hakim untuk menetapkan hak asuh asuh

\footnotetext{
V. Hadiyono, Rika Saraswati, Anastasia Anita Carolina Hadi, Jauw, Angelia YS dan Jordan Febriyanto, Penerapan Asas Penghargaan Terhadap Hak Berpendapat Anak Dalam Putusan Pengadilan Tentang Hak Pemeliharaan Dan Mendidik Anak ( Studi Kasus Di Pengadilan Negeri Semarang), Penelitian Fakultas Hukum dan Komunikasi, 2016; lihat juga Rika Saraswati dan V.Hadiyono, Penghargaan Hak Berpendapat Anak di Pengadilan: Studi Kasus di Pengadilan Negeri Semarang, 13(2) Sawwa Jurnal Studi Gender, 2018. http://journal.walisongo.ac.id/index.php/sawwa/article/view/3016, diakses 29 Maret 2019, pukul 21:00.
} 
adalah keinginan orang tua, keinginan anak, dan hubungan antara anak dengan orang tuanya, kesehatan fisik dan mental orang-orang yang terlibat dengan anak. Hal ini diperkuat dengan pendapat para hakim yang menyatakan bahwa ibu dan bapak tetap berkewajiban memelihara dan mendidik anaknya semata-mata berdasarkan kepentingan anak.

Hal ini sesuai dengan peraturan perundang-undangan yang berlaku di Indonesia sebagaimana diatur di dalam Pasal 41 dan Pasal 49 UU Perkawinan. Kewajiban untuk memelihara dan mendidik anak oleh ayah dan ibu setelah perceraian juga diatur di Pasal $105 \mathrm{KHI}$ yang menentukan hak asuh kepada ibu jika anak belum mumayyiz atau belum berumur 12 tahun, apabila anak sudah mumayyiz ia berhak memilih untuk mendapatkan hak asuh dari ayah atau ibunya.

\section{Kebijakan Pengadilan Bagi Orangtua yang akan Bercerai agar Memiliki Rencana Pengasuhan (Parenting Plans) Bersama}

Berdasarkan data yang diperoleh melalui kuesioner dan wawancara kepada empat (4) hakim di Pengadilan Negeri Semarang dan satu (1) hakim di Pengadilan Agama Semarang, ternyata tidak semua hakim pernah memerintahkan kepada para pihak yang berperkara untuk membuat kesepakatan di luar pengadilan tentang hak asuh bersama. Terdapat dua hakim yang pernah memerintahkan agar para pihak membuat kesepakatan dengan hasil ada yang terlaksana dan ada yang tidak dilaksanakan. Selanjutnya, hanya ada satu hakim yang berpendapat bahwa kesepakatan tentang perencanaan hak asuh bersama atau parenting plans seharusnya memang dilakukan oleh para pihak, namun hal tersebut jarang dilakukan.

Terdapat empat (4) Hakim yang menyatakan bahwa tidak pernah memerintahkan untuk membuat kesepakatan di dalam Pengadilan tentang hak asuh bersama dan menuangkan ke dalam perjanjian karena para hakim ini berpendapat bahwa hal itu cukup dilakukan melalui putusan pengadilan. Selanjutnya, terdapat satu (1) Hakim yang menyatakan pernah memerintahkan pada saat mediasi dan perintah itu dilaksanakan oleh para pihak. Perencanaan pengasuhan (parenting plan) meliputi jadwal pengasuhan dan segala sesuatu yang 
terkait dengan permasalahan hukum yang berkaitan dengan kewajiban orang tua dan hak-hak anak. Perencanaan ini meletakkan tanggung jawab dari setiap orang tua dalam menyediakan kebutuhan anak pada saat pelaksanaannya berdasarkan usia anak dan kedewasaannya. Suatu perencanaan juga memuat hal-hal tentang penyelesaian di masa mendatang dalam hal terjadi perselisihan antara orangtua, khususnya penyelesaian perselisihan melalui mediasi. ${ }^{38}$

Melalui jadwal pengasuhan (parenting time) di dalam perencanaan pengasuhan maka hak-hak anak terjamin keberkelanjutan dan secara berkala dapat melakukan kontak yang bermakna dengan kedua orang tua. Alokasi perencanaan jadwal pengasuhan dimaknai kedua orang tua harus memiliki periode waktu tertentu di mana seorang anak tinggal dengan atau berada di bawah pengasuhan dan pengawasan dari setiap orang tua. Periode waktu ini tidak harus sama jumlahnya, tetapi harus berakibat pada lama tinggalnya dengan setiap orang tua. ${ }^{39}$

Dalam hal perencanaan pengasuhan dituangkan ke dalam putusan pengadilan atas dasar kesepakatan yang sudah dibuat oleh para pihak maka hal tersebut dapat digunakan sebagai dasar agar para pihak menepati kesepakatan untuk memperhatikan hak anak untuk bertemu dengan salah satu orang tua dalam hal terjadi perpisahan. Selain itu, untuk menghidari terjadinya pengingkaran kesepakatan atau tidak dilaksanakannya putusan hakim untuk mengunjungi anak, atau pihak yang mendapat hak asuh tunggal menghalangi pihak yang hanya mendapatkan akses untuk bertemu dengan anaknya. Dengan demikian maka hal tersebut akan memudahkan pihak-pihak untuk menggugat hak-haknya yang tidak terpenuhi kepada pemerintah, baik melalui pengadilan atau ke lembaga-lembaga lain yang terkait dengan pemenuhan dan perlindungan hak-hak anak.

\footnotetext{
38 J. Herbie DiFonzo, supra no. 10, hlm., 61-65.

39 Id.
} 


\section{Ketersediaan Program Mediasi Mengenai Pengasuhan Bersama}

Berdasarkan putusan pengadilan yang diteliti dan hasil dari kuesioner dan wawancara kepada hakim dapat diketahui bahwa mediasi yang diberikan oleh majelis hakim lebih menitikberatkan pada kehendak para pihak untuk bercerai atau tidak bercerai. Pengadilan melalui mediator hakim tidak pernah memerintahkan para pihak untuk membuat perencanaan pengasuhan bagi anakanak hasil perkawinan apabila mediasi ternyata tidak membuahkan hasil. Putusan Pengadilan Nomor: 158/Pdt.G/2016/PN.Smg telah menunjukkan hal tersebut:

“...Menimbang bahwa para pihak yang berperkara terlebih dahulu menempuh upaya mediasi untuk mengakhiri perselisihan antara mereka secara damai, dan para pihak sepakat menyerahkan sepenuhnya kepada Majelis Hakim untuk menunjuk mediator dan untuk itu Majelis Hakim menunjuk Hakim mediator. Mediasi telah dilakukan pada 10 Mei 2016 dan Mediator memberitahukan bahwa mediasi yang dilakukan telah gagal mencapai kesepakatan..". 40

Kemudian pada Putusan Pengadilan Nomor: 428/Pdt.G/2014/PN.Smg juga menunjukkan situasi yang sama:

“...Majelis Hakim telah mengupayakan perdamaian melalui mediasi dengan menunjuk Hakim mediator. Berdasarkan laporan Mediator tanggal 30 Desember 2014, Mediasi telah dinyatakan gagal". ${ }^{41}$

Putusan Pengadilan Nomor: 217/Pdt.G/2014/PN.Smg melalui pertimbangan majelis hakim juga menunjukkan bahwa para pihak diwajibkan menyelesaikan perkara melalui mediasi dan majelis hakim telah menunjuk mediator hakim dalam perkara tersebut; dalam putusan tersebut diketahui bahwa mediator hakim telah berusaha mendamaikan kedua belah pihak, dan berdasarkan laporan mediator tanggal 14 Agustus 2014 mediasi telah gagal. ${ }^{42}$ Putusan Pengadilan Nomor: 1901/Pdt.G/2017/PA.Smg juga menunjukkan hal yang sama ${ }^{43}$ bahwa setelah perdamaian yang diupayakan tidak berhasil, baik melalui majelis hakim maupun mediator hakim, maka tidak ada lagi perintah

Putusan Pengadilan Nomor: 158/Pdt.G/2016/PN.Smg, hlm.,3.

Putusan Pengadilan Nomor: 428/Pdt.G/2014/PN.Smg, hlm., 3.

Putusan Pengadilan Nomor: 217/Pdt.G/2014/PN.Smg, hlm., 5.

Putusan Pengadilan Nomor: 1901/Pdt.G/2017/PA.Smg, hlm., 4-5. 
untuk membuat perencanaan pengasuhan yang sebenarnya sangat penting bagi kepentingan anak-anak para pihak.

Mengingat bahwa salah satu tugas dan fungsi hakim sebagai mediator menurut Peraturan Mahkamah Agung (PERMA) Nomor 1 Tahun 2016 tentang Prosedur Mediasi di Pengadilan adalah untuk menginventarisasi permasalahan dan mengagendakan pembahasan berdasarkan skala proritas. Oleh karena itu, hakim yang bertugas sebagai mediator harus mengingatkan kebutuhan dan kepentingan terpenuhinya hak-hak anak mereka. Dengan demikian, sangat penting bagi hakim memahami subtansi Undang-Undang Perlindungan Anak Tahun 2002 dan 2014 sehingga ketika mendapatkan tugas sebagai mediator dapat melakukan sosialisasi tentang hak-hak anak kepada para pihak, dan juga mewajibkan para pihak untuk membuat perencanaan pengasuhan bersama.

Sudah seharusnya menjadi kebijakan bagi pemerintah Indonesia melalui lembaga pengadilan, baik Pengadilan Negeri maupun Pengadilan Agama, untuk mewajibkan para pihak yang akan bercerai agar membuat perencanaan pengasuhan bersama demi memenuhi kebutuhan dan kepentingan hak-hak anak setelah terjadinya perceraian. Selain itu, hakim sebagai mediator memiliki tugas untuk memfasilitasi dan mendorong para pihak menelusuri dan menggali kepentingan para pihak, mencari berbagai pilihan penyelesaian yang terbaik bagi para pihak, dan bekerja sama untuk mencapai penyelesaian, termasuk dalam merumuskan kesepakatan bersama.

Membuat kesepakatan bersama untuk perencanaan pengasuhan bagi para pihak yang akan bercerai setelah mediasi tidak berhasil mencapai kesepakatan sangat diperlukan karena perencanaan pengasuhan yang disepakati dan hasilnya dibawa ke dalam proses pengadilan akan memberikan kekuatan hukum dan diharapkan mampu melindungi kepentingan terpenuhinya hak-hak anak, khususnya hak atas biaya pemeliharaan dan pendidikan. Kesepakatan bersama untuk perencanaan pengasuhan bersama menjadi sangat penting karena sistem hukum yang ada untuk melindungi hak-hak anak setelah terjadinya perceraian pada umumnya dilakukan melalui eksekusi dengan cara mengajukan gugatan ke pengadilan. Akan tetapi, upaya ini juga tidak maksimal karena kendala-kendala 
yang ada, khususnya dari pihak perempuan sebagai penggugat yang biasanya kemampuan ekonominya terbatas dan pemahaman hukum yang rendah maupun dari biaya pengajuan gugatan eksekusi yang tidak murah. ${ }^{44}$ Berkaitan dengan sistem dan mekanisme hukum yang ada untuk melindungi hak-hak anak setelah terjadinya perceraian para hakim yang diberi kuesioner dan diwawancarai memberi jawaban yang beragam sebagaimana yang dimuat dalam tabel berikut ini.

Tabel 3: Sistem dan Mekanisme yang Dimiliki Pengadilan untuk Melindungi HakHak Anak

\begin{tabular}{|c|c|}
\hline Hakim & Jawaban \\
\hline Hakim PN 45 & $\begin{array}{l}\text { Mekanisme melalui mendengarkan keterangan anak (judicial activision). Setelah } \\
\text { putusnya perkawinan mekanisme melalui gugatan di pengadilan misalnya } \\
\text { tentang pencabutan hak asuh. }\end{array}$ \\
\hline Hakim & $\begin{array}{lcccc}\begin{array}{l}\text { Tidak memiliki mekanisme tersebut, } \\
\text { berhubungan dengan hak dan kewajiban para pihak }\end{array} & \text { kecuali } & \text { hanya } & \text { yang } \\
\end{array}$ \\
\hline Hakim PN ${ }^{47}$ & Tidak memiliki \\
\hline Hakim $\mathrm{PN}^{48}$ & $\begin{array}{l}\text { Ada, berupa penetapan atau penunjukan sementara pihak mana yang akan } \\
\text { memelihara anak sebelum putusan pengadilan (mediasi) }\end{array}$ \\
\hline Hakim $\mathrm{PA}^{49}$ & $\begin{array}{l}\text { Anak yang berada di bawah umur adalah hak ibunya untuk } \\
\text { mengasuh kecuali bunya tidak cakap dan hak tersebut tidak } \\
\text { mutlak karena ayahnya tetap diberi akses untuk berhubungan } \\
\text { dengan anaknya dan mencurahkan kasih sayangnya pada anak. }\end{array}$ \\
\hline
\end{tabular}
Sumber: Rika Saraswati, Emanuel Boputra dan Yuni Kusniati, 201850

Jawaban tersebut menunjukkan adanya perbedaan mengenai ketersediaan sistem dan mekanisme di pengadilan untuk melindungi hak-hak anak. Mengingat dalam kenyataannya banyak anak-anak yang tidak terpenuhi hak-haknya oleh ayah atau ibu yang tidak memperoleh hak asuh maka kesepakatan dalam perencanaan pengasuhan bersama menjadi sangat penting dan seyogyanya dipertimbangkan agar menjadi suatu keharusan bagi para pihak untuk membuat

44 Gheavina Ferisma W, 2., Pelaksanaan Kewajiban Pembayaran Nafkah Anak yang Ditetapkan dalam Putusan Pengadilan Agama Semarang, Skripsi S1 Fakults Hukum dan Komunikasi Unika Soegijapranata, Semarang; Lihat juga Savira Dita Setiawati, 2018, Pelaksanaan Asas Peradilan Sederhana, Cepat dan Biaya Ringan di Pengadilan Negeri Semarang dan Pengadilan Agama Semarang, Skripsi S1 Fakults Hukum dan Komunikasi Unika Soegijapranata, Semarang, 2018. Kuesioner dan wawancara dengan Hakim EP pada tanggal 19 Juli 2018, pukul 10:00.

46 Kuesioner dan wawancara dengan Hakim MY pada tanggal 19 Juli 2018, pukul 10:00.

47 Kuesioner dan wawancara dengan Hakim NN pada tanggal 19 Juli 2018, pukul 10:45.

48 Kuesioner dan wawancara dengan Hakim EN pada tanggal 19 Juli 2018, pukul 10:45.

49 Kuesioner dan wawancara dengan Hakim MS pada tanggal 16 Juli 2018, pukul 09:00.

50 Rika Saraswati, Emanuel Boputra, Yuni Kusniati, supra no.12. 
dan menjalankannya. Hakim sebagai mediator diberi kewajiban oleh pengadilan untuk melihat hal ini sebagai skala prioritas yang harus dilakukan oleh para pihak ketika mereka telah memutuskan untuk bercerai dan menolak perdamaian yang ditawarkan oleh hakim sebagai mediator. Hal ini sebaiknya tidak hanya berlaku bagi hakim sebagai mediator di Pengadilan Negeri Semarang dan Pengadilan Agama Semarang, tetapi juga berlaku bagi para mediator non-hakim yang mendapat tugas menangani perkara perceraian di mana ada kepentingan anak yang terlibat di dalamnya. Hal ini tentunya diharapkan juga dilakukan oleh para mediator hakim (dan mediator non-hakim) di pengadilan negeri dan pengadilan agama di seluruh wilayah di Indonesia. Dengan memerintahkan para pihak untuk membuat perencanaan pengasuhan maka para mediator hakim tersebut dapat memberikan wacana tentang kesetaraan gender kepada para pihak untuk dan dalam melakukan pengasuhan bersama melalui perencanaan pengasuhan Bersama tersebut demi kepentingan terbaik anak.

\section{Penutup}

Ketentuan dalam Pasal 41 UU Perkawinan dianggap oleh para hakim kurang jelas mengatur pengasuhan tunggal atau pengasuhan bersama, meskipun demikian para hakim melalui putusan-putusannya telah melaksanakannya dengan memberikan pengasuhan kepada ibu, ayah atau keduanya baik melalui pengasuhan tunggal atau pengasuhan bersama. Pengadilan Agama Semarang dan Pengadilan Negeri Semarang belum memiliki kebijakan yang mewajibkan orang tua yang akan bercerai membuat perencanaan pengasuhan bersama bagi anakanak mereka. Selain itu, dalam proses mediasi juga belum terdapat kebijakan yang mewajibkan suami-istri yang akan bercerai membuat kesepakatan mengenai hak asuh bersama.

Mengingat bahwa persoalan hak anak setelah orang tua bercerai terjadi di seluruh wilayah Indonesia, maka pengadilan negeri dan pengadilan agama di seluruh wilayah di Indonesia seharusnya memiliki kebijakan dan pedoman yang mewajibkan para pihak yang akan bercerai agar membuat perencanaan pengasuhan bersama demi terpenuhinya hak-hak anak. Kewajiban tersebut dapat 
dilakukan pada saat proses mediasi maupun pada saat proses persidangan berlangsung, sehingga ketika putusan dijatuhkan dan ditetapkan oleh Hakim ada jaminan bagi anak-anak untuk kehidupannya di masa depan.

\section{Daftar Pustaka}

\section{Buku:}

Rika Saraswati, Hukum Perlindungan Anak di Indonesia, PT. Citra Aditya Bakti, Bandung, 2015, hlm.25-26.

\section{Jurnal:}

Bala, N., V. Talwar and J. Harris, 'The Voice of Children in Canadian Family Law Cases' 24 Cdn. Family Law Q. 221, 2005

Cochran, R.F. Jr. 'The Search for Guidance in Determining the Best Interests of the Child at Divorce: Reconciling the Primary Caretaker and Joint Custody Preferences' 20(1) University of Richmond Law Rev. 1985. $<$ http://scholarship.richmond.edu/lawreview/vol20/iss1/2>).

DiFonzo, J. Herbie, From the Rule of One to Shared Parenting: Custody Presumptions in Law and Policy, 52 (2) Family Court Review. 214, 2014.

Elrod, Linda D, Reforming the System to Protect Children in High Conflict Custody Cases, 28(2) William Mitchell Law Review. 506, 2001.

Elrod, Linda. D. and M. D. Dale, 'Paradigm Shifts and Pendulum Swings in Child Custody: The Interests of Children in the Balance' 42 (3) Family Law Q. 381, 2008.

Fidler, Barbara J and Rachel Birnbaum, Child Custody Disputes: Private and Public Assesment, 25 (2) Canadian Family Law Quarterly. 137, 140. 2006

Moloney, Lawrie, Child Focused Parenting after Separation: Socio Legal Developments and Challenges, 21(2) ANZJ Fam. 61, 2000.

Rika Saraswati, dan V. Hadiyono, Penghargaan Hak Berpendapat Anak di Pengadilan: Studi Kasus di Pengadilan Negeri Semarang, 13(2) Sawwa Jurnal Studi Gender, 2018. http://journal.walisongo.ac.id/index.php/ sawwa/article/view/3016

Saffer, Martha, Joint Custody, Parental Conflict and Children's Adjustment to Divorce: What the Social Science Literature Does and Does Not Tell Us, 26 (3) Canadian Family Law Quarterly. 285, 2007

\section{Referensi Tidak Dipublikasi:}

Gheavina Ferisma W, Pelaksanaan Kewajiban Pembayaran Nafkah Anak yang Ditetapkan dalam Putusan Pengadilan Agama Semarang, Skripsi S1 Fakultas Hukum dan Komunikasi Unika Soegijapranata, Semarang, 2018, tidak dipublikasi. 
Ivan Ricardo Gitowardojo, Pemenuhan Hak Anak Untuk Bertemu Dengan Salah Satu Orang Tuanya Yang Tidak Mendapatkan Hak Asuh SetelahTerjadinya Perceraian Menurut Pasal 14 Ayat (2) Undang-Undang Nomor 35 Tahun 2014 Tentang Perubahan Atas Undang-Undang Nomor 23 Tahun 2002 Tentang Perlindungan Anak (Studi Kasus Putusan No.30/ Pdt.G/2016/PN. Smg dan Putusan No.45/Pdt.G/2016/PN.Smg), Skripsi S1, Fakultas Hukum dan Komunikasi Unika Soegijapranata Semarang, 2017, tidak dipublikasi.

Rika Saraswati, Emanuel Boputra dan Yuni Kusniati, Tinjauan terhadap Sistem Pengasuhan Anak dari Pengasuhan Tunggal Menjadi Pengasuhan Bersama sebagai Perwujudan Pemenuhan Asas Kepentingan Terbaik Anak, penelitian-LPPM Universitas Katolik Soegijapranata, 27-30, 2018, tidak dipublikasi.

Savira Dita Setiawati, Pelaksanaan Asas Peradilan Sederhana, Cepat dan Biaya Ringan di Pengadilan Negeri Semarang dan Pengadilan Agama Semarang, Skripsi S1 Fakults Hukum dan Komunikasi Unika Soegijapranata, Semarang, 2018, tidak dipublikasi.

V. Hadiyono, Rika Saraswati, Anastasia Anita Carolina Hadi, Jauw, Angelia YS dan Jordan Febriyanto, Penerapan Asas Penghargaan terhadap Hak Berpendapat Anak Dalam Putusan Pengadilan tentang Hak Pemeliharaan dan Mendidik Anak (Studi Kasus Di Pengadilan Negeri Semarang), Penelitian Fakultas Hukum dan Komunikasi, 2016, tidak dipublikasi.

\section{Peraturan Perundang-undangan:}

Undang-Undang R.I., No. 1. Tahun 1974, Perkawinan

Undang-Undang R.I., No. 23 Tahun 2002, PERLINDUNGAN ANAK

Undang-Undang R.I., No. 35 Tahun 2014, Perubahan Atas Undang-Undang Nomor 23 Tahun 2002 tentang Perlindungan Anak.

Instruksi Presiden R.I., No. 1 Tahun 1991, Penyebarluasan Kompilasi Hukum Islam, Pasal 105.

\section{Putusan Pengadilan:}

Putusan Pengadilan Negeri Semarang Nomor: 217/Pdt.G/2014/PN.Smg Putusan Pengadilan Negeri Semarang Nomor: 428/Pdt.G/2014/PN.Smg Putusan Pengadilan Negeri Semarang Nomor: 158/Pdt.G/2016/PN.Smg Putusan Pengadilan Agama Semarang Nomor: 1901/Pdt.G/2017/PA.Smg

\section{Kuesioner dan Wawancara:}

Hakim E P pada tanggal 19 Juli 2018. Hakim MY pada tanggal 19 Juli 2018. Hakim NN pada tanggal 19 Juli 2018. Hakim EN pada tanggal 19 Juli 2018. Hakim MS pada tanggal 16 Juli 2018. 